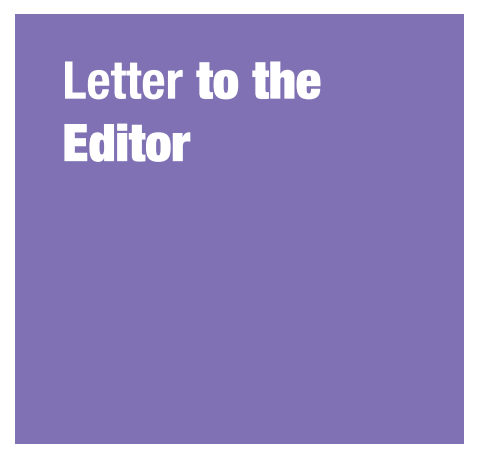

\title{
Science, Technology, Engineering and Mathematics (STEM) Comics as Cognitive Learning Enhancers for Malaysians
}

\author{
INDERJIT Kaur \\ Faculty of Science and Technology, Universiti Kebangsaan Malaysia, Bangi, \\ Selangor, Malaysia
}

Submitted: 8 Sep 2019

Accepted: 9 Sep 2019

Online: 4 Nov 2019

To cite this article: Inderjit K. Science, technology, engineering and mathematics (STEM) comics as cognitive learning enhancers for Malaysians. Malays J Med Sci. 2019;26(5):158-159. https://doi.org/10.21315/ mjms2019.26.5.16

To link to this article: https://doi.org/10.21315/mjms2019.26.5.16

Dear Editor,

I read with interest the manuscript titled 'Expanding opportunities for science, technology, engineering and mathematics subjects teaching and learning: connecting through comics' by Adnan et al. (1).

It is indeed a very plausible article highlighting an interesting approach of making science, technology, engineering and mathematics (STEM) learning among Malaysian primary students more interesting. The approach of using STEM comics as proposed by this paper is an important innovation in the way STEM subjects are taught in Malaysian schools. This approach could instill an early interest as shown by this study for the primary school students to be involved in STEM fields. It is still an issue in Malaysia where students are afraid of choosing the science stream in their secondary school (2).

The approach proposed by this study could be an encouraging factor in instilling interest of students into the science field at a very young age. Comic strips have been proven by previous studies to be an effective tool to create interesting representation of teaching materials even from teachers with no background in comic designing (3).

Thus, the approach being proposed by this study is indeed practical and has high potential to be implemented in Malaysian primary schools by enhancing education via cognitive neurosciences.

\section{Acknowledgements}

None.

\section{Conflict of Interest}

None.

\section{Funds}

None.

\section{Correspondence}

Dr Inderjit Kaur

Alumni of Pusat Permata Pintar Negara

BSc Biochemistry (University Kebangsaan Malaysia)

Faculty of Science and Technology,

Universiti Kebangsaan Malaysia,

43600 Bangi, Selangor, Malaysia.

Tel: +603 89215555

Fax: +603 89214097

E-mail: inder9713@gmail.com 
Letter to the Editor | STEM comics as cognitive learning enhancers

\section{References}

1. Adnan M, Abdullah JM, Md Ibharim LF, Tan WH, Janan D, Abdullah N, et al. Expanding opportunities for science, technology, engineering and mathematics subjects teaching and learning: connectivity through comics. Malays J. Med Sci. 2019:26(4):127-133. https://doi.org/10.21315/ mjms2019.26.4.15

2. Inus, K. Don't be scared of science stream. Kuala Lumpur, Malaysia: New Straits Times; 4 May 2016. https://www.nst.com.my/ news/2017/03/143502/dont-be-scared-sciencestream
3. Lazarinis F, Mazaraki A, Verykios VS, Panagiotakopoulos C. E-comics in teaching: evaluating and using comic strip creator tools for educational purposes. The 10th International Conference on Computer Science \& Education (ICCSE 2015). 2015 July 22-24; Fitzwilliam College, Cambridge University, UK: New York: IEEE; 2015. https://doi.org/10.1109/ ICCSE.2015.7250261 